\title{
Municipal amalgamations and their effects: a literature review
}

\section{Abstract}

Municipal amalgamation reforms have been advocated as ways to improve efficiency, reduce costs, and enhance capacity in local government service provision. Research on the consequences of amalgamations has reached maturity in terms of theories, research designs and methods, justifying a systematic survey of results. This article provides a synthesis of the empirical literature published over the last 20 years, organizing the effects of amalgamations into three categories: economic efficiency and cost savings, managerial implications, and democratic outcomes. Despite the significant variation across countries and reforms, some regularities emerge: cost savings being primarily limited to general administration expenditures (wages, office supplies, and so on), few changes in the quality of local services, and the diminished quality of local democracy. Several studies point to amalgamation reforms experiencing a trade-off between efficiency and democracy.

Keywords

Municipal amalgamations $\bullet$ fragmentation $\bullet$ efficiency $\bullet$ costs $\bullet$ democratic outcomes

(c) University of Warsaw - Faculty of Geography and Regional Studies

\author{
Antonio F. Tavares \\ Political Science Research Center \\ School of Economics and Management, \\ University of Minho, 4710-057 Braga, Portugal \\ e-mail: atavares@eeg.uminho.pt \\ Received: 9 February 2018 \\ Accepted: invited paper
}

Introduction

An extensive review of 50 years of evidence of the relationship between the structure and performance of local governments highlights the virtues of polycentrism and local governments as units of governance (Bish 2001). The idea of amalgamations capable of producing "large integrated bureaucracies supervised by full-time politicians and run by professional bureaucrats" (Bish 2001: p.18) is frequently contested by public choice scholars and described as a monolithic solution incapable of reflecting the diverse preferences of citizens. Yet, despite the arguments praising the merits of polycentrism and decentralized governance, the second half of the 20th century witnessed the proliferation of territorial reforms centred on the amalgamation of municipal governments. This trend could be seen across the globe, including such diverse places as Canada, Japan, Australia, New Zealand, Israel, and multiple countries in Western Europe.

In Western Europe, following an initial set of amalgamation reforms in the post-war period, the first two decades of the $21^{\text {st }}$ century have seen a resurgence of this tendency. Surprisingly, however, most of the territorial reforms aiming to merge local governments were not supported by rigorous empirical research and reliable data analysis. In fact, if anything, scholars and policymakers have remained separate realms, with academic research having a very limited influence on governmental reforms. Nevertheless, the mounting empirical research addressing the economic, managerial, and democratic impacts of amalgamation reforms justifies a systematic review of the evidence. This article attempts to tackle this lacuna by providing tentative answers to the following questions: 1 ) What are the consequences of local government amalgamations? and 2) Is there a trade-off between the efficiency of outputs and democratic outcomes resulting from municipal amalgamations?

The goal of this review is not to search for the 'optimal size' of local governments identified in the literature, but rather to assess the outcomes of amalgamation reforms. While size is an inherent element of all amalgamation reforms and should be taken into account as part of a context-specific analysis of these reforms, the discussion of 'optimal size' as a theoretical focus is beyond the scope of this article. Instead, the review highlights the impacts of amalgamation reforms in three major domains: economic efficiency, managerial goals, and democratic outcomes.

By focusing on the empirical evidence of municipal amalgamation reforms available by country, state or region, I seek to highlight different types of effects as well as to identify patterns of success and failure in amalgamation reforms across the globe. It is hoped that the product of this exercise in systematization will help elected officials and policy-makers seeking advice on whether or not to pursue this type of territorial reform.

This article is organized as follows. Following this introduction, the second section presents a summary of the theoretical arguments supporting and opposing local government amalgamations. This discussion focuses on three major categories of expected consequences: 1) economic efficiency; 2) managerial impacts; and 3) democratic outcomes. The third section describes the research strategy and the criteria for the selection of empirical articles included in this review of the literature. Section four reviews the 52 empirical studies organized under the same headings as the theoretical discussion 
in section two. The article closes with a set of conclusions and recommendations based on the extensive review.

\section{Theoretical Background}

According to the Encyclopaedic Dictionary of Public Administration, amalgamation (or merger) is the process of "the fusion of one or more municipal entities into a new organization" (Belley 2012: 1). Similarly, Robert Bish (2001) defines amalgamation as a reduction in the number of multi-purpose local government units through consolidation (Bish 2001: 14). Depending on the enabling legislation, this process can be either voluntary or mandatory, but municipal amalgamations should be distinguished from another type of consolidation: territorial annexations. In the process of annexation, one local government unit (usually of larger size and greater resources) absorbs part(s) of (an)other unit(s) (Belley 2012).

Both consolidation processes - amalgamation and annexation - produce larger territorial units, with potential impacts on economic efficiency, managerial effectiveness, and democratic outcomes. This survey of the literature is focused exclusively on the impacts of amalgamation reforms, since these can be more easily tracked due to the systematic nature of amalgamations, usually organized and promoted with top-down control, and covering a sizeable proportion or the totality of the local government system. This section describes the theoretical impacts of amalgamations by focusing on three types of potential consequences: economic efficiency, managerial effectiveness, and democratic outcomes.

\section{Economic Expectations}

Amalgamation reforms are often motivated by the argument that larger municipalities are able to provide local public services at lower unit costs due to economies of scale. This focus is also known as productive efficiency - that is, the optimal method to produce goods and services at the lowest possible cost. However, this argument is erroneous for at least three reasons (Boyne 1992; 1996; Dollery and Fleming 2006; Dollery et al. 2008). First, economies of scale are not uniform across the whole gamut of services provided by local governments. In capital-intensive and infrastructure services, there will be potential gains with increased population size because fixed costs can be spread across more residents, but typically, in the case of labour-intensive services, these gains are non-existent because providing more services entails hiring more employees to respond to this demand. As the mix of capitalintensive and labour-intensive services in a given municipality tilts towards the latter, scale economies are less likely to be available. Second, managerial costs tend to increase significantly after a certain population size threshold so that diseconomies of scale are likely in large municipalities. Third, population size is an imperfect measure of production costs, since these also depend on such diverse factors as the weather, topography, age of residents, local income, service quality, and seasonal variations in population (for example, tourism or migration).

Past reviews of the empirical literature seem to support these theoretical arguments. Back in 2009, a review of the extant literature by the LUARC Commission indicated that local governments for communities between 25,000 and 250,000 residents are the most efficient, with diseconomies of scale occurring in jurisdictions above 250,000 , and communities below 25,000 suffering from inefficiencies when providing capitalintensive and specialized services (Holzer et al. 2009). However, the authors of this report highlight that "over 80 percent of municipal services are of a routine and labor-intensive nature" (p.4) and therefore less likely to generate economies of scale with the added size after amalgamations. In these cases, managerial efficiency is more important than size for achieving efficiencies, because most inefficiencies in larger municipalities stem from management control and excessive administrative burden (Holzer et al. 2009). There is also evidence that certain services (for example, routine police patrol services) are efficiently performed in smaller communities, whereas larger municipalities are more efficient in performing special investigations (Holzer et al. 2009). Overall, the report concludes that the theoretical consensus regarding the economic expectations of amalgamations seems to be that the provision of specialized and capital-intensive services becomes more efficient with size increases after amalgamations (Holzer et al. 2009).

The supporters of intermunicipal cooperation and contracting out for municipal services highlight an additional theoretical argument against amalgamations. Local government officials concerned with reaping economies of scale can enter into more flexible arrangements, such as resource-sharing agreements with their neighbours, and/or purchase services from private providers or other local governments, thereby avoiding the use of a more radical type of territorial reform (Bish 2001; Dollery and Fleming 2006; Tavares 2015).

Incontrastwith thetheoreticalargumentsagainstamalgamation reforms, other authors have argued in favour of consolidation and increased municipal size. Large-scale local governments are thought to favour local economic development, not only because of their comprehensive view of planning activities but also because they benefit from lower interest rates and represent lower risk in investments to finance expensive infrastructure (Denters et al. 2014). Economic efficiency (and managerial effectiveness) levels can also increase in amalgamated municipalities as a result of the higher degrees of specialization and professionalization of larger local governments (Denters et al. 2014). Free-riding due to interjurisdictional spillovers is also less likely to occur in more consolidated regions, because amalgamations will secure a better match between the boundaries of the jurisdiction and the catchment areas of services (Swianiewicz 2010).

In summary, the diverse set of factors that contribute to explain varying unit costs in the provision of local services cast doubt on the degree of success of amalgamation reforms in achieving economic efficiency. However, amalgamations can generate local governments capable of addressing regional-type issues due to their large size in terms of population, geographical area, and administrative size. These conflicting theoretical expectations will be compared with the empirical results described in the fourth section of this review.

\section{Functional and Managerial Expectations}

Besides the productive efficiency concerns discussed in the previous section, the theoretical discussion focuses on the potential effects of amalgamations on allocative efficiency that is, the optimal distribution of goods and services that takes into account the preferences of citizen-voters. According to the classic argument developed by Tiebout (1956), citizens 'vote with their feet' to choose their preferred combination of local taxes and publicly provided services. From this point of view, smaller communities are more homogeneous due to population sorting effects between communities and, as a result, local officials are better able to tailor policies that fit the preferences of a larger proportion of their residents (Oakerson 1999). The Decentralization Theorem proposed by Wallace Oates (1972) argues that, in the absence of cost savings from centralization and interjurisdictional externalities, fiscal responsibilities should be decentralized. The corollary of Oates' theorem is that 'individual local governments are presumably much closer to the people [...], they possess knowledge of both local preferences and cost conditions that a central agency is unlikely to have" (Oates 1999: 1123).

The combination of the arguments presented by Tiebout (1956) and Oates (1999) suggests that, in a polycentric regional context, 
the self-sorting of population between communities leads to significant community differentiation (Howell-Moroney 2008). When residents are provided with a relatively large number of choices over where to live, communities often become highly differentiated in terms of spending on public services, levels of taxation, financial resources of residents, and the racial composition of the municipality's population (Lowery 2000; Ostrom, Tiebout and Warren 1961; Oakerson 1999). As a result, the regional landscape tends to display significant heterogeneity of preferences between communities and high homogeneity of preferences within communities. Due to the competition between local governments and the homogeneity of preferences within communities, managerial effectiveness and the quality of services are expected to increase in more fragmented, non-amalgamated contexts.

In a similar vein, an often-cited managerial argument suggests that consolidation of municipalities generates an increase in coordination and management costs due to more complex bureaucratic structures associated with larger local governments (Denters et al. 2014). The critics tend to explain the growth of bureaucratic organizations as resulting from demand pressures for public services. Amalgamations reduce competition among local governments for taxpayers voting-with-their-feet, creating a situation where uncontrollable spending goes unchecked. The Leviathan hypothesis, developed by Brennan and Buchanan (1977), argues that fragmentation reduces spending through more decentralised government structures which are smaller relative to the size of the local economy. Fiscal decentralisation promotes local government competition and increases the information available to residents about the price and quality of public services. In addition, "fragmentation supports experimentation and innovation" (Swianiewicz 2002, p.11) and the diffusion of these practices is more likely across jurisdictions in polycentric metropolitan areas.

In contrast to the benefits for managerial efficiency and effectiveness underlined by public choice scholars, others have argued that post-amalgamation local governments are able to deliver more and better-quality services to their residents (Swianiewicz 2010). The argument is that the increase in size can lead to a more diverse and specialized set of services, including planning, public transportation, police, and fire services (Newton 1982). High levels of functional differentiation can only be accomplished in larger municipalities and this has been one of the primary motives to pursue amalgamation reforms. The belief that larger local governments are able to deploy a fullsize bureaucracy, professional administrators, and effective coordination to deliver a broad set of public services explains the tendency to combine amalgamation reforms with high functional differentiation in several European countries, particularly in the North (Denters et al. 2014). The predictability of bureaucratic organization can help improve citizen satisfaction with service delivery, not only in terms of efficiency and effectiveness, but also in less tangible values such as equity and perceived fairness.

Just as with economic efficiency, the expected outcomes of amalgamations for managerial effectiveness seem to vary according to the theoretical background of the researchers. Public Choice scholars argue that pre-amalgamation municipalities may be more responsive due to Tiebout-type competition effects among local governments and higher preference homogeneity within communities, whereas consolidation advocates suggest that post-amalgamation municipalities can also be more responsive because of the improved coordination, capacity and professionalization of local bureaucracies.

Democratic Expectations

The urban politics literature provides two different logics for why the costs of participation are affected by the presence of multiple decision venues in regions and what this means for the quality of civic and political engagement in the community. Both logics presume that population sorting follows on from fragmentation and that the community differentiation produced by polycentricism directly affects the efficacy of engaging in political and community life.

In smaller jurisdictions, close contact between councillors and citizens is more likely and politicians are more accountable to their local constituencies. An increase in scale due to amalgamation may lead to a decline of community and social trust and, in turn, to a decline in political trust (Denters 2002). For Oakerson, polycentric governance structures are able to promote more consensual decision making because smaller-scale local governments are better able to effectively capture relevant 'communities of interests'. This type of sorting helps to produce the shared values thought to encourage participation and to facilitate decision making. Works focusing on the role of social capital in political participation find that participation levels are significantly higher in demographically and economically homogeneous communities than in settings with diverse populations (Costa and Kahn 2003). Large-scale amalgamated governments without smaller nested governments combine highly diverse interests into a single comprehensive political jurisdiction and this situation creates conflict. Oakerson concluded that "if small municipalities are constituted so as to define relatively coherent communities of interest, with each one conducting its politics in a less adversarial style, they increase the potential for the politics of more inclusive units of governments to be conducted in a less adversarial style as well" (p.33). And a less adversarial style of politics makes it possible for a truly 'civil' society to emerge, where businesses and residents work as co-producers with municipal governments in effective urban governance, rather than "act mainly on the demand side as advocate or special pleader" (p.33). Thus, polycentric structures lead to larger numbers of municipal governments with relatively small populations and these smaller governments enhance political and civic participation. Consistently with this theoretical reasoning, Oliver (2001) found that people living in smaller cities were more likely to report voting in municipal elections, participating in political meetings, and contacting city officials.

Kelleher and Lowery (2004) argue that the absence of conflict is not necessarily an indicator of healthy governance. They suggest that consensual politics occurring in highly fragmented metropolitan areas may mean that larger problems are not confronted at all, or simply must be dealt with in other ways. They note that these problems may just be 'off the political agenda', because nested institutions may lead to a lack of venues for confronting larger scale problems. In these cases, Kelleher and Lowery argue, issues of inequality will not have a venue where they can be raised and addressed. This basic criticism has been advanced by several scholars (Howell-Moroney 2008) and its implication is that amalgamations can potentially help to address these problems by increasing political participation as a response to conflict.

According to the classical argument developed by Dahl and Tufte (1973), the increase in the capacity to provide more services in amalgamated municipalities can also improve the quality of local democracy. The increase in population size is likely to generate more fruitful political debates, stronger civil society, and enhanced pluralism (Swianiewicz 2002). If amalgamations are able to increase service delivery capacity, citizens are more likely to get involved in politics because the number of relevant political issues and service functions performed by local governments also increases. This argument assumes that pre-amalgamation municipalities are too small to harbour organized interest groups capable of making a difference through large-scale political action. In contrast, amalgamations can facilitate organized political participation 
MISCELLANEA GEOGRAPHICA - REGIONAL STUDIES ON DEVELOPMENT

Vol. $22 \cdot$ No. $1 \cdot 2018 \cdot$ pp. 5-15 - ISSN: 2084-6118 • DOI: 10.2478/mgrsd-2018-0005

as community groups, political parties and the media tend to be more present, active, and robust (Newton 1982). An increase in the number, density, and diversity of interest groups and civil society organizations leads to increased pluralism and political competition, and these in turn can generate higher responsiveness to policy preferences on the part of elected leaders (Denters et al. 2014; Verba and Nie 1972). Others have suggested that citizens' perceptions of integration into a wider city-region can also be an important facilitator for consolidation reforms (Lidström 2013). In addition, fewer income disparities may develop in consolidated municipalities than in highly fragmented settings (Swianiewicz 2010). By reducing the need for income redistribution across local governments, amalgamations can potentially reduce inequalities between residents in metropolitan areas.

Smaller jurisdictions increase participation due to increased opportunities for contact with local officials as well as a higher likelihood of casting the decisive vote in local elections, whereas amalgamationscangeneratelarger, morecompetitiveand pluralistic local democracies, capable of increasing responsiveness (Dahl and Tufte 1973; Denters et al. 2014). While pre-amalgamation municipalities may be more responsive due to increased opportunities for effective participation, post-amalgamation municipalities can also be responsive because of improved political competition (Dahl and Tufte 1973; Denters et al. 2014).

This section presented the theoretical expectations regarding the consequences of amalgamations. Territorial reforms seeking to merge municipalities have intended and unintended impacts on economic efficiency, managerial effectiveness, and democratic outcomes. However, scholars have disagreed frequently about the expected outcomes of territorial reforms, with public choice supporters arguing against amalgamations and in favour of more fragmented, polycentric regional settings, and consolidation advocates supporting mergers in defence of stronger bureaucracies with increased technical and professional expertise. The time has come to contrast these conflicting theoretical predictions with the results of a vast set of empirical analyses focusing on the consequences of amalgamations. Before I begin, however, the following section will describe the process leading to the selection of the works under review in section four.

\section{Research Strategy / Selection of Empirical Studies}

This review of the literature on the consequences of municipal amalgamations focuses on academic articles published between 1985 and 2017 and with full text availability in the Web of Science and Scopus search engines. In addition to this time frame, I have also searched Google Scholar for additional pre-1985 references relevant to this research topic. While these references are not included in the review of empirical results, some of them were used in the theoretical section of the paper.

The selection of key words was based on the research questions stated in the introduction ("What are the consequences of local government amalgamations?" and "Is there a trade-off between efficiency outputs and democratic outcomes resulting from municipal amalgamations?") and the search was designed to be as encompassing as possible. The following key words were used in the search: "municipal amalgamations", "local government amalgamations", "municipal mergers", "local government mergers", "municipal" AND "territorial reforms", "local government" AND "territorial reforms", and "territorial local government reforms" (see Table 1).

After this initial selection based on automatic key word searches, all the remaining filtering processes were conducted manually (see Figure 1 for a summary). First, all duplicates and papers unrelated to amalgamations were excluded based on the abstracts. A total of 192 articles were excluded at this stage. The remaining 83 were included for further analysis.
Table 1. Web of Science and Scopus Key Word Search Results

\begin{tabular}{|c|c|c|}
\hline Search Terms & $\begin{array}{c}\text { Web of } \\
\text { Science }\end{array}$ & Scopus \\
\hline "municipal amalgamations" & 32 & 61 \\
\hline "local government amalgamations" & 4 & 20 \\
\hline "municipal mergers" & 34 & 61 \\
\hline "local government mergers" & 3 & 5 \\
\hline "municipal" AND "territorial reforms" & 4 & 14 \\
\hline "local government" AND "territorial \\
reforms" & 6 & 26 \\
\hline "territorial local government reforms" & 1 & 1 \\
\hline TOTAL & 84 & 188 \\
\hline
\end{tabular}

Second, giventhatthis reviewfocusesonlyontheconsequences of the amalgamation of multi-purpose governments, the second step was to exclude all articles addressing the consequences of amalgamation reforms involving single policy-type units, such as the amalgamation of police services (Lithopoulos 2015) or health care services (Bates et al. 2011).

Next, I also opted to exclude a smaller set of articles discussing topics only marginally related to the horizontal amalgamation of local governments: 1 ) the impacts of vertical consolidation (Andrews 2015); 2) the processes leading to failed amalgamation attempts (Mussari and Ruggiero 2017); 3) the preferences for amalgamations among municipal mayors, council members or chief executives (Sørensen 2006); 4) the effects of de-amalgamation (Drew and Dollery 2014); and 5) the creation of sub-municipal local councils to counter the negative effects of municipal amalgamations originating large municipalities (Thuesen 2017). In total, five articles were excluded at this stage.

Fourth, articles discussing the causes of amalgamations were also excluded, even though they were still useful for theoretical discussion (see Askim, Klausen, Vabo and Bjurstrøm 2016; Strebel 2016; Erlingsson, Ödalen and Wångmar 2015; and Calciolari, Cristofoli and Macciò 2013). Four articles were excluded based on this criterion.

Fifth, I excluded all articles addressing the effects of amalgamations in a literature review without original data analysis (Dollery and Yamazaki 2017; de Ceuninck, Reynaert, Steyvers and Valcke 2010; Dollery, Crase and O'Keefe 2009; Dollery, Byrnes and Crase 2007; Dollery and Crase 2004; Sancton 1996) and purely theoretical papers, either including formal modelling (Furukawa 2014) or not (Drew, Grant and Fisher 2017; Swianiewicz 2010; Dollery, Byrnes and Crase 2008; Bish 2001). While these eleven articles were excluded from the empirical review, some of them were employed to set up the theoretical discussion.

Lastly, pre-amalgamation analyses were eliminated at this stage as they project the possible consequences of amalgamations rather than the actual consequences (Drew, Kortt and Dollery 2017; Fahey, Drew and Dollery 2016; Kortt, Dollery and Drew 2016; Sinnewe, Kortt and Dollery 2015; Tavares and Rodrigues 2015; Callanan, Murphy and Quinlivan 2014; Drew and Dollery 2014; 2014a; Drew, Kortt and Dollery 2013). A recent simulation of the financial and administrative consequences of amalgamations in the Veneto region in Italy using a tool for ex-ante policy assessment (Rizzi and Zanette 2017) was also excluded. Nine articles were eliminated at this stage.

Stages 2 to 6 employ a set of criteria to eliminate 31 articles considered not relevant to the discussion of the consequences of municipal amalgamations. A total of 52 articles consisting of empirical analyses according to the criteria stated above were selected for the empirical review. This review investigating the outcomes of amalgamation reforms is conducted in the next section. 
Records identified through database searching (272) $\Downarrow$

Duplicates removed (192)

$\Downarrow$

Records without empirical evidence and/or theory only (22) $\Downarrow$

Full text articles assessed for further eligibility (61)

$\Downarrow$

Records excluded: no consequences are systematically analysed (9)

$\Downarrow$

Articles included in the analysis (52)

Figure 1. Criteria for the Selection of Articles

The Consequences of Amalgamations: Economic, Managerial and Political Effects

In order to organize the information contained in the 52 articles selected for analysis, a database was set up in spreadsheet format with each article's basic information, including author(s), title, journal, year, keywords, subject, methodology, research questions/empirical objective, and country. In addition, the database also includes the economic, managerial, and democratic outcomes of the amalgamation reforms.

The journal publishing the largest number of articles about the consequences of municipal amalgamations, by a long way, is Local Government Studies, with 11 articles. Publications on this topic in top journals in the field of Political Science are fairly rare: two articles appeared in the American Political Science Review and one in the American Journal of Political Science, all three articles focusing on Denmark. In addition, Public Management Review, Public Choice, Journal of Urban Affairs and Urban Affairs Review published two articles each during the period under analysis.

The country most represented in this set of studies is Denmark (14 articles), followed by Canada (10, primarily about amalgamations in the province of Ontario), Australia (6, primarily about New South Wales), Japan (5), Sweden (4), and the Netherlands (3). In terms of time frame, the period 2010-2018 is the most represented decade in this group of studies (41 articles), indicating the recent surge in studies of the effects of municipal amalgamations. Ten of the remaining 11 articles were published in the previous decade (2000-2009) and only one article was published in the period 1990-1999 (Nelson 1992).

The level of methodological sophistication varies significantly across all articles reviewed in this section. Overall, the empirical studies of the Danish territorial reform of 2004 are, by far, the most ambitious, diverse, and technically well-executed. As a whole, they represent, by and large, the benchmark for empirical research into the consequences of municipal amalgamations. The most frequently employed method for assessing the effect of municipal amalgamations is difference-in-differences (14 articles). The majority of the remaining articles also use some form or combination of quantitative data analysis techniques (ordinary least squares regression, panel data with fixed effects, synthetic control method, and propensity score matching, among others) (18 articles). The remaining articles employ an assorted group of quantitative and/or qualitative techniques, such as comparative analysis of descriptive financial data, qualitative content analysis, in-depth case study analysis, principal component analysis or descriptive analysis of survey and interview responses (perception-based data).

Economic Efficiency

The first thing that can be said about the effects of municipal amalgamations on economic efficiency and cost savings is that the promises of these territorial reforms are left largely unfulfilled. Despite some positive results regarding the reduction of administrative spending in specific amalgamation reforms, which can be seen in the works by Blom-Hansen et al. (2014) in Denmark, Blesse and Baskaran (2016) in Brandenburg (Germany), Miyazaki (2017) in Japan, or Cobban (2017) in Ontario (Canada), the majority of the studies fail to find significant reductions in expenditures as a result of municipal amalgamations. In some cases, the authors find that the reduction of expenditures in general administration ${ }^{1}$ is offset by increased spending in other service categories. Other studies find unused economies of scale, but these effects tend to be small.

\section{Economies of Scale and Costs}

A large number of studies employ municipal expenditures as the dependent variable. Bikker and van der Linde (2016) use panel data on municipal spending on local public administration (2005-2014) by Dutch municipalities and find unused economies of scale of $17 \%$ for the average municipality, higher for smaller municipalities and lower for larger ones. This result indicates that efficiency could be improved with increases in population size, presumably stemming from amalgamations. Allers and Geertsma (2016) find no significant effect on aggregate spending or taxation, but confirm the reduction in spending on general administration as a result of amalgamations in the Netherlands.

Blesse and Baskaran (2016) study amalgamations in the Land of Brandenburg (Germany) and find significant reductions in administrative expenditures after compulsory mergers, presumably due to the choice of 'optimal partners' with whom to amalgamate. In contrast, voluntary mergers had no effect on expenditures, a result the authors attribute to the choice of 'suboptimal partners' in voluntary amalgamations. Roesel (2017) investigated the effects of a merger of 22 county-sized local governments into 10 in Saxony, Germany, applying a synthetic control method to panel data (1998-2013). The author found no reduction in total expenditures or expenditures for administration, education or social care and no scale effects in jurisdictions of more than 100,000 inhabitants.

The mixed findings associated with the Danish reform become quite obvious in more recent and sophisticated empirical work. Blom-Hansen et al. (2014) use administrative costs per capita and annual change in administrative costs per capita and find evidence of considerable scale effects. In contrast, Blom-Hansen et al. (2016) investigate 9 policy areas: day care, schools, elderly care, children with special needs, roads, culture, administration, labour market activities, and total expenditures. The authors find that cost savings in some areas are offset by deterioration in others, while for most public services jurisdiction size did not matter at all.

In Sweden, the 1952 amalgamation reform had a negative impact on expenditures for municipalities under a critical size, but lower expenditure growth could only be observed in the case of the amalgamation of highly fragmented municipalities of equal size and not when a large municipality amalgamated with a smaller one (Hanes 2015). A positive effect of population growth was found for the municipalities that were small in size prior to the reform (under 2,000 inhabitants) (Hanes and Wikström 2008). According to the analysis, municipal amalgamations had no effect on the municipal income growth patterns but led to a slight overall increase in the population of amalgamated municipalities which were small prior to the reform. Using time series data of municipal expenditures (1942-1987) to measure municipal sector size in Sweden, Nelson (1992) concludes that decentralization, measured by the number of local government units serving a

${ }^{1}$ General administration expenditures include salaries for elected officials and administrative personnel, office furniture and utensils, and building maintenance, among others. 
given population, constrains the influence of institutional factors (rent-seeking, bureaucracy) on local budgets as long as these units exceed some minimal threshold size. This conclusion provides support for the fragmentation perspective and against municipal amalgamations.

In Finland, Moisio and Uusitalo (2013) compare 82 amalgamated municipalities with 82 municipalities in a control group focusing on per capita spending in the period 1970-1981. The study finds that municipal mergers were not conducive to lower per capita spending. In most spending categories, the per capita expenditure increased more in the merged municipalities than in the comparison group. Only in the general administration did the per capita spending decrease by about $8 \%$; however, similarly to the Danish case, this decrease was far smaller than the increase in spending in other categories. Reingenwertz (2012) conducted a study in Israel involving 244 municipalities (21 amalgamated and 219 non-amalgamated) using panel data (1999-2007). Amalgamations resulted in a decrease of about $9 \%$ in municipal expenditures, suggesting the presence of economies of scale. The author finds no evidence of a decrease in the level of services provided to residents of amalgamated municipalities, but more recent research highlights the trade-off between efficiency and democracy present in the Israeli amalgamation reform (Zeedan 2017).

An investigation of amalgamations in Queensland (Australia) examines pre- and post-amalgamation (2006/07 n = 114 and $2009 / 10 n=57$ ) data for scale economies (Drew et al. 2016). For the 2006/07 data, the authors find evidence of economies of scale for councils with populations up to 98,000 , and thereafter diseconomies of scale. Eight percent of councils in 2006/07 (ten councils) - representing $64 \%$ of the state's population - exhibited diseconomies of scale. For the 2009/10 data, the average cost curve remained almost stationary at 99,000 residents per council, but almost $25 \%$ of all councils (thirteen councils) were now found to exhibit diseconomies of scale. As a result of the compulsory merger programme, the proportion of Queensland residents in councils operating with diseconomies of scale increased to $84 \%$.

Aulich et al. (2014) investigate amalgamations in Australia and New Zealand using 8 interviews and 15 case studies and find little evidence of consistent economies of scale from consolidation. However, both case studies and interviews indicated that consolidation generated economies of scope and what the authors describe as 'strategic capacity'. While it was not possible to disaggregate the data for particular sizes of local authority, the enhancement of strategic capacity was more obvious through processes of consolidation in larger ones and less so in smaller, more remote ones.

Miljan and Spicer (2015) studied 3 small amalgamated municipalities in Ontario (Canada), employing a comparative analysis of financial data, and concluded that amalgamation did not result in cost savings or lower property taxes. They found significant increases in property taxes, compensation for municipal employees, and long-term debt in both amalgamated and non-amalgamated communities, suggesting there was no tangible, financial benefit from amalgamation. The authors also found that spending on certain services and remuneration also increased significantly. The data broadly indicate that post-2000 intra-municipal trends in cost indicators, such as fire and safety costs per household, have remained stable within the group analysed, or even increased since amalgamation.

Slack and Bird (2013) investigate the effect of mergers in Toronto (Canada) using 1988-2008 data and find that per household expenditures increased for fire, solid refuse, and parks and recreation services, with libraries being the only service under analysis that was unaffected by the merger. In contrast, a recent study using 1998-2010 data finds that increasing the size of local jurisdictions reduces the cost of local administration (Cobban 2017). Despite the evidence of the presence of economies of scale for administrative services, this study fails to find similar support for other services (fire, parks and recreation, and public works).

In Japan, Miyazaki (2017) conducted a study involving panel data for approximately 1,600 municipalities and used difference-indifferences and an instrumental variable methodology. The author finds that municipal current expenditures per capita increase immediately after the amalgamation, but then gradually decline. The trend-including regression yields a decline in expenditure subsequent to consolidation. The author also highlights that many empirical studies of amalgamation suffer from fundamental methodological problems: the adoption of an instrumental variable strategy is crucial to avoid biased estimates (Miyazaki 2017).

\section{Common Pool Effects}

Several authors explore possible common pool resource effects in the pre-amalgamations period and find consistent support for this argument. Common pool effects appear in association with the opportunistic spending hypothesis stating that local government spending increases in pre-amalgamation periods as a result of specific 'free rider' behaviour (Swianiewicz 2018).

Blom-Hansen (2010) studies the Danish case and finds that local councillors exploited 'last minute spending' to finance local projects before 'closing time'. However, the article also shows that it is the availability of a common pool that matters, not its size. In contrast, Hansen (2014) finds that pre-amalgamation project size tends to increase with common pool size. The paper finds positive, statistically and economically significant effects of the availability and size of a common pool in the final year of the treatment period. The importance of the number of districts over district population suggests a reappraisal of the law of $1 / n$ as originally formulated. In Sweden, municipalities that merged in 1952 increased their debt between 1948 and 1952 when the reform could be anticipated (Jordahl and Liang 2010).

In Finland, Saarimaa and Tukiainen (2015) used a difference-indifferences technique to investigate 306 municipalities that did not merge, 49 with weak incentives to merge, and 50 with strong incentives to merge. The authors found that the stronger freeriding incentive a municipality faced, the more it increased its debt and spent its cash reserves in the period 2000-2008. Similarly, in Japan, Hirota and Yunoue (2017) found that subordinate merger partners suffer from adverse fiscal conditions and create a fiscal common pool problem in public projects just before the mergers.

Another twist in the opportunistic spending story is the hypothesis tested for the Danish amalgamation reform that political budget cycles are larger in new political units. Contrary to theoretical predictions, political budget cycles seem to be of a smaller scale in the new municipalities, but only regarding budget cycles in budgetary overruns (Aaskoven 2017).

\section{Perception-Based Studies}

Lastly, perception-based studies of efficiency display severe methodological limitations when compared to those reviewed above. Contrary to the expectation of the provincial government of Ontario (Canada) that amalgamations would result in more efficient service delivery, in every jurisdiction, except the former city of Kingston, the majority of citizens surveyed felt that the value they were receiving for their taxes declined after amalgamation (Kushner and Siegel 2003). Cost savings predicted by those supporting consolidation did not materialize (Kushner and Siegel 2005a). Neither were there significant cost increases. The results indicate that the relative size of the municipalities in an amalgamation could have an impact on the efficiencies generated by the amalgamation. In Central Elgin, a relatively large township absorbed two small adjacent villages with fairly positive results, whereas the other 
two amalgamations, which involved municipalities of relatively equal size, did not produce such positive results.

\section{Managerial Implications}

Empirical studies investigating the managerial implications of local government amalgamations are quite diverse in their use of dependent variables. The results are organized in three subsections: financial performance outcomes, quality of service studies, and perception-based studies.

\section{Financial Management Outcomes}

Hansen et al. (2014) find that "measured on the balance between revenues and expenses, liquid assets and debts, municipal amalgamations improve the fiscal outcomes of the municipalities in a five-year perspective" after the mergers, "although the prereform effects tend to be negative. For liquidity and debt, however, the improvement only entails re-establishing the levels prior to the reform" (p.196).

Houlberg and Pedersen (2015) find that amalgamated municipalities in Denmark budget with lower expenditure growth but are unable to stick to these budgets. The more complex the amalgamation, the more difficult it is for the municipality to bring their budgets under control after the reform. In addition, the larger the population, the lower the budget overruns. One interpretation of this result is that larger budgets are less vulnerable to changes over the fiscal year than smaller budgets, while another could be that larger municipalities have a more professionalized administrative staff skilled with legal and economic competences.

Allers and van Ommeren (2016) find that amalgamations do not result in higher interest rates. Interest rates paid by recently amalgamated municipalities are lower than those paid by intermunicipal organizations.

\section{Service Quality}

The studies investigating the effect of amalgamations on service quality using objective measures are not very numerous, but they overwhelmingly refute the idea that amalgamations result in lower service quality. The majority report either null findings or positive effects.

The study conducted in the Netherlands by Allers and Geertsma (2016) shows no change in the quality of public services as a result of amalgamations. Similarly, Reingenwertz (2012) finds no evidence of decrease in the level of services provided to residents of amalgamated municipalities in Israel. In Switzerland, early work by Steiner (2003) suggests that in five merged municipalities performance quality generally improves, but amalgamations seldom ease the municipal budget situation. Much more recent and detailed work by Steiner and Kaiser (2017) in Switzerland indicates partial support for the hypothesis of a positive effect on public service delivery, professionalization of staff and municipal autonomy, and an inconclusive effect on municipal finances.

In Denmark, the results of a study conducted by Krøtel et al. (2017) suggest that public management related to daily operations is not affected by size, whereas overall tasks such as creating a vision, providing political counselling to the mayor, and representing the administration on external matters, are positively affected by size changes resulting from amalgamations.

One of the least investigated aspects of amalgamation reforms is the causal relationship between population size and the contracting out of public service delivery in local governments. In Denmark, a study by Foged (2016) tested this relationship in the context of the municipal amalgamation reform and showed that it differs across policy sectors. Size is negatively related to the contracting out of services with high fixed costs due to scale economies, and positively associated with contracting for services that are difficult to measure, probably due to higher administrative and technical capacity in larger municipalities. Furthermore, the effect of an increase in population size due to amalgamation is positive for contracting out tasks in free-choice markets, since private contractors find these markets more appealing.

\section{Perception-Based Studies}

Studies of citizen perceptions of the impacts of amalgamations on managerial outcomes are fairly rare and Canada seems to be a preferred locus of these studies. Poel (2000) conducted a survey of 752 respondents involving businesses and residents in Halifax, Nova Scotia (Canada). This study reveals that, in 1999, most citizens did not have a favourable assessment of the Halifax Regional Municipality (HRM) amalgamation decision, nor of the performance of their Council, individual councillors or mayor. Citizens did not see the geographical, social and economic diversity of the HRM region as a strength and, with the exception of the solid waste management variable, did not link amalgamation in a positive way to municipal service improvements, considering most services to have remained unchanged. Other studies conducted in Canada indicate that in all three cases in Ontario (Central Elgin, Kingston and Chatham-Kent), there was a significant expression of both positive and negative opinions in the lead-up to the amalgamations, but these opinions made little difference to the outcome. The pockets of dissatisfaction with amalgamations did not translate into significant complaints by residents regarding the quality of services (Kushner and Siegel 2005). Reese (2004) investigated the outcomes of the merger of 12 municipalities into the city of Ottawa and found that governmental reorganization did not have a substantial effect on taxes or services.

In Australia, Ryan et al. (2015) surveyed 2,006 individuals and found that citizens were ambivalent towards amalgamations, although their attitudes were influenced by particular demographic characteristics and attitudes towards representation, belonging, service delivery requirements and the associated costs. The results suggest that, excluding impacts on the local government sector itself, structural reform may not be the distressing issue it is often portrayed as.

Using propensity score matching, Suzuki and Sakuwa (2016) investigate population growth rates in 3,253 municipalities in Japan over the period 2000-2010 at the pre-merger level and find that municipal mergers negatively affect population growth for municipalities if they are not the largest municipalities among their merging partners. While not a consequence for the quality of services per se, the amalgamation of asymmetric local governments can result in higher tax burdens and increased commuting costs for the residents in the smaller local government community (Furukawa 2014).

Finally, Takagishi et al. (2012) surveyed 570 employees in amalgamated municipalities and found that the impact of the loss of value of jobs is associated with psychological stress responses. Increased workload does not trigger a stress response. To our knowledge, this is the only empirical study investigating the consequences of mergers on the management of human resources.

\section{Democratic Outcomes}

Most of what we know about the democratic and political consequences of municipal amalgamations comes from systematic research conducted in Denmark, examining multiple outcome variables. Research conducted elsewhere is scarce and usually limited to inspecting one dimension of all possible effects for democracy. Taken as a set, all studies in this category indicate negative consequences for democracy as a result of mergers, with only two exceptions: Spicer (2012) points out positive outcomes in Hamilton, Ontario, where it was found that 
councillors from amalgamated municipalities vote together, and Steiner and Kaiser (2017) find no negative effects for local democracy based on perception data.

Lassen and Serritzlew (2011) used survey data collected before and after the Danish reform and found that jurisdiction size has a causal, detrimental effect on citizens' internal political efficacy. The authors identify the citizens' ability to understand local politics as the dimension of internal political efficacy most affected by the size increases associated with amalgamations.

Kjaer et al. (2010) show that amalgamations have led to an increase in the perceived influence of leading councillors visà-vis back-bench councillors and a decrease in the perceived influence of the council vis-à-vis its top administrative officers. Other research indicates that local parties were punished at the polls for implementing municipal amalgamations decided by the central government (Kjaer and Klemmensen 2015). This work also shows that the political parties holding the mayoralty in times of amalgamations tend to designate very tenured mayors as candidates, thus missing the positive first-term incumbency effect, which a new mayor could have acquired. The results of a citizen survey reveal higher levels of dissatisfaction with the municipal services in amalgamated municipalities, indicating a significant political cost for mayoral parties associated with the implementation of amalgamations.

Jakobsen and Kjaer (2016) investigated a possible numerical over-representation of the periphery in the legislature of the amalgamated jurisdictions. This hypothesis was tested empirically using a sample of 66 amalgamations with different centreperiphery dimensions. The results confirm the over-representation hypothesis, in terms of both representation by seats in jurisdiction councils (descriptive representation) and politicians' advancement of local interests (substantive representation).

In Germany (Saxony), Roesel found evidence that mergers decreased the number of candidates and voter turnout in district elections, while vote shares for populist right-wing parties increased. This study suggests a 'worst of both worlds' situation. Amalgamations failed to reduce district level expenditures and resulted in a deterioration of the quality of local democracy.

A study conducted in Buloke Shire (Australia) using social network analysis shows that, despite the passage of more than a decade, significant residual resentment from forced amalgamations remains evident across most communities. There is a widespread perception that the reforms have undermined rather than improved the operation of local government across the municipality, and that post-amalgamation political structures have largely failed to effectively reconcile the diverse and sometimes disparate interests of Buloke's constituent towns and communities. Social network analysis also suggests that much work remains to be done to develop a meaningful sense of community within the new administrative boundaries, with very little evidence of cross-community cooperation, coalition building or issue-based interaction detected.

In Ontario (Canada), Kushner and Siegel (2003) found that most residents saw no change in community attachment, and those who did were equally split between those who saw an increase and those who saw a decrease. The authors also found that a significant minority did feel a sense of attachment to the new municipality. Variation across municipalities is significant, with initial opposition remaining strong in Pittsburgh and Port Stanley and strong initial opposition in Chatham-Kent diminishing over time. The authors conclude that "it is very difficult to generalize about results" and that "some additional support for the amalgamations is emerging, but this is happening very slowly and is unfolding differently in different jurisdictions" (p.58).

In Israel, Zeedan (2017) investigates 24 amalgamated governments using panel data for voter turnout (1998-2013) and finds that amalgamations reduce the quality of local democracy in terms of lower voter turnout and representation. The author recommends that a new amalgamated government must be sufficiently small to maximize local democracy and sufficiently large to maximize economies of scale.

\section{Conclusions}

This article provides a synthesis of the empirical literature published over the last 20 years, organizing the effects of municipal amalgamations into three categories: economic efficiency and cost saving results, managerial implications, and democratic outcomes. Early studies reached very general conclusions, indicating, for example, that "the success of municipal consolidation depends on the distinct history, as well as the spatial and economic circumstances, of the region considering reform" (Vojnovic 2000: p.385). While this may very well have been true at the turn of the century, the empirical literature on municipal amalgamations is now sufficiently developed to provide some tentative generalizations.

If anything, this survey of the literature recommends caution regarding the expectations of amalgamation reforms and not the unbridled optimism we often see in consultancy and governmental reports. First, regarding economic efficiency and spending, the studies allow us to expect some cost savings, primarily in general administration functions, but the overall reaping of significant economies of scale is unlikely, perhaps with the exception of highly fragmented local government systems. When controlling for other factors, cost savings tend to disappear, and even when there are savings in general administration, these are often offset by diseconomies of scale and additional spending in other service categories. The single most decisive and consistent result is that local actors behave rationally and, when faced with top-down compulsory amalgamation reforms, opportunistic spending prior to the actual reform is the norm.

Second, studies investigating the implications of amalgamations for the quality of local service delivery offer some support to the idea that larger local governments are able to provide better quality services to their citizens. The majority of these studies reports either null findings or positive effects, thus suggesting that this is the category where advocates of local government amalgamations can be more optimistic about the results of these reforms. Combined with the cost saving impacts discussed above, these findings also suggest that improving service quality through mergers comes at a price: an increase in the average size of local governments enhances their ability to deliver more diverse and better-quality services to citizens, but these enhanced local government bureaucracies are more costly to run.

Third, the overwhelming majority of the studies investigating the effects of amalgamations for the quality of local democracy show disappointing results. Mergers tend to depress turnout rates, decrease the number of candidates in local elections, reduce internal political efficacy, and negatively affect the level of community attachment of residents. The findings in this category are quite robust across countries and research designs employed, suggesting that these are the 'unavoidable' outcomes of amalgamation reforms, more concerned with economic efficiency and cost savings than with the negative impacts for local democracy. The main implication is that many amalgamation reforms experience a trade-off between efficiency and democracy.

In a recent review, Swianiewicz (2018) underscores the fact that almost all empirical studies of the effects of municipal mergers have focused on compulsory, top-down reforms and little is known about the degree of success of voluntary mergers. This gap in the research is relevant because it suggests that the unfulfilled 
promises of amalgamations are likely to be the product of the mandatory nature of the processes rather than the amalgamation itself as a policy tool for territorial reform. Given what we know from previous studies, one would have to concur with Swianiewicz (2018) in arguing that forced amalgamations are only likely to be a solution in very specific and limited circumstances, namely for local government systems experiencing extreme fragmentation.

Given the results of this survey of the literature, I join the call of Erlingsson and Öddalen (2017) arguing that local self-government must be taken into consideration when deciding on amalgamation reforms, particularly if these reforms are being imposed by the upper levels of government (p.340). Possible alternatives to municipal amalgamations which take into account local self-government aspirations include intermunicipal cooperation agreements and contracting out in the private and non-profit sectors. Holzer et al. (2009) argue that "contracting, sharing, or receiving specialized services from a large entity can make selected services more efficient" (p.18) and this can be accomplished without inflicting harm upon local democracies.

\section{References}

*Aaskoven, L 2017, 'Polity age and political budget cycles: Evidence from a Danish municipal reform', European Journal of Political Economy, forthcoming.

*Alexander, D 2013, 'Crossing boundaries: Action networks, amalgamation and inter-community trust in a small rural shire', Local Government Studies, vol. 39, no. 4, pp. 463487.

*Allers, MA, Geertsema, JB 2016, 'The effects of local government amalgamation on public spending, taxation, and service levels: Evidence from 15 years of municipal consolidation', Journal of Regional Science, vol. 56, no. 4, pp. 659-682.

*Allers, MA, van Ommeren, B 2016, 'Intermunicipal cooperation, municipal amalgamation and the price of credit', Local Government Studies, vol. 42, no. 5, pp. 717-738.

Andrews, R 2015, 'Vertical consolidation and financial sustainability: Evidence from English local government', Environment and Planning C: Government and Policy, vol. 33, pp. 1518-1545.

Askim, J, Klausen, JE, Vabo, SI, Bjurstrøm, K 2016, 'What causes municipal amalgamation reform? Rational explanations meet Western European experiences, 2004-13', in G Bouckaert, S Kuhlmann (eds.) Local Public Sector Reforms in Times of Crisis: National Trajectories and International Comparisons, London: Palgrave Macmillan.

*Askim, J, Klausen, JE, Vabo, SI, Bjurstrøm, K 2017, 'Territorial upscaling of local governments: A variable-oriented approach to explaining variance among Western European countries', Local Government Studies, vol. 43, no. 4, pp. 555-576.

*Aulich, C, Sansom, G, McKinlay, P 2014, 'A fresh look at municipal consolidation in Australia', Local Government Studies, vol. 40, no. 1, pp. 1-20.

Bates, LJ, Lafrancois, BA, Santerre, RE 2011, 'An empirical study of the consolidation of local public health services in Connecticut', Public Choice, vol. 147, pp. 107-121.

Belley, S 2012, 'Amalgamation (or Merger)' In L. Côté and J.-F. Savard (eds.), Encyclopedic Dictionary of Public Administration, [online], www.dictionnaire.enap.ca Retrieved on January 17, 2018.

*Bikker, J, van der Linde, D 2016, 'Scale economies in local public administration', Local Government Studies, vol. 42, no. 3, pp. 441-463.

Bish, RL 2001, 'Local government amalgamations: Discredited nineteen-century ideas alive in the twenty-first', Commentary, C. D. Howe Institute, 150, pp. 1-29.

*Blesse, S, Baskaran, T 2016, 'Do municipal mergers reduce costs? Evidence from a German federal state', Regional Science and Urban Economics, vol. 59, pp. 54-74.

*Blom-Hansen, J 2010, 'Municipal amalgamations and common pool problems: The Danish local government reform in 2007', Scandinavian Political Studies, vol. 33, no. 1, pp.51-73.

*All references preceded by a "*” were included in the comprehensive literature review of the effects of municipal amalgamations
*Blom-Hansen, J, Houlberg, K, Serritzlew, S 2014, 'Size, democracy, and the economic costs of running a political system', American Journal of Political Science, vol. 58, no. 4, pp. $790-803$.

*Blom-Hansen, J, Houlberg, K, Serritzlew, S, Treisman, D 2016, 'Jurisdiction size and local government policy expenditure: Assessing the effect of municipal amalgamation', American Political Science Review, vol. 110, no. 4, pp. 812-831.

Boyne, G 1992. 'Local government structure and performance: Lessons from America?' Public Administration, vol. 70, no. 3, pp. 333-357.

Boyne, G 1996. 'Scale, performance and the New Public Management: An empirical analysis of local authority services', Journal of Management Studies, vol. 33 no. 6, pp. 809-826.

Brennan, G, Buchanan, JM 1977, 'Towards a Tax Constitution for Leviathan', Journal of Public Economics, vol. 8, no. 3, pp. 255-273.

Calciolari, S, Cristofoli, D, Macciò, L 2013, 'Explaining the reactions of Swiss municipalities to the 'amalgamation wave', Public Management Review, vol. 15, no. 4, pp. 563583.

Callanan, M, Murphy, R, Quinlivan, A 2014, 'The risks of intuition: Size, costs and economies of scale in local government', The Economic and Social Review, vol. 45, no. 3, pp. 371403.

Carr, JB 2004, 'Whose Game do we Play? Local Government Boundary Change and Metropolitan Governance', In R. Feiock (Ed.), Metropolitan Governance: Conflict, Competition, and Cooperation, Washington: Georgetown University Press, pp. 212-239.

*Cobban, TW 2017, 'Bigger is better: Reducing the cost of local administration by increasing jurisdiction size in Ontario, Canada, 1995-2010', Urban Affairs Review, forthcoming.

De Ceuninck, K, Reynaert, H, Steyvers, K, Valcke, T 2010, 'Municipal amalgamations in the Low Countries: Same problems, different solutions', Local Government Studies, vol. 36 , no. 6 , pp. 803-822.

Denters, B, Goldsmith, M, Ladner, A, Mouritzen, PE, Rose, L 2014, Size and Local Democracy, Edward Elgar.

Dollery, B, Byrnes, J, Crase, L 2008, 'Australian local government amalgamation: A conceptual analysis of population size and scale economies in municipal service provision', Australasian Journal of Regional Studies, vol. 14, no. 2, pp. 167-175.

Dollery, B, Crase, L 2004, 'Is bigger local government better? An evaluation of the case for Australian municipal amalgamation programs', Urban Policy and Research, vol. 22, no. 3, pp. 265-275.

Dollery, B, Crase, L, O'Keefe, S 2009, 'Improving efficiency in Australian local government: Structural reform as a catalyst for effective reform', Geographical Research vol. 47, no. 3, pp. 269-279. 
Dollery, B, Fleming, E 2006, 'A conceptual note on scale economies, size economies and scope economies in Australian local government', Urban Policy and Research, vol. 24, no. 2, pp. 271-282.

*Dollery, B, Ting, SK 2017, 'Counting the cost: An analysis of the post-merger performance of the Clarence Valley Council in New South Wales', Economic Analysis and Policy, vol. 56, pp. $72-78$.

Drew, J, Dollery, B 2014, 'Would bigger councils yield scale economies in the Greater Perth Metropolitan Region? A critique of the Metropolitan Local Government Review for Perth local government', Australian Journal of Public Administration, vol. 73, no. 1, pp. 128-137.

Drew, J, Dollery, B 2014a, 'The impact of metropolitan amalgamations in Sydney on municipal financial sustainability', Public Money \& Management, vol. 34, no. 4, pp. 281-288.

*Drew, J, Dollery, B 2014b, 'Separation anxiety: An empirical evaluation of the Australian Sunshine Coast Regional Council de-amalgamation', Public Money \& Management, vol. 34, no. 3, pp. 213-220.

Drew, J, Kortt, MA, Dollery, B, 2013, 'A cautionary tale: Council amalgamation in Tasmania and the Deloitte Access Economics Report', Australian Journal of Public Administration, vol. 72, no. 1, pp. 55-65.

*Drew, J, Kortt, MA, Dollery, B, 2016, 'Did the big stick work? An empirical assessment of scale economies and the Queensland forced amalgamation program', Local Government Studies, vol. 42, no. 1, pp. 1-14.

Drew, J, Kortt, MA, Dollery, B, 2017, 'No Aladdin's Cave in New South Wales? Local government amalgamation, scale economies, and data envelopment analysis specification', Administration \& Society, vol. 49, no. 10, pp. 1450-1470.

Drier, P, Mollenkopf, J, Swanstrom, T 2004, Place Matters: Metropolitics for the Twenty-First Century, Lawrence: University of Kansas Press.

*Elklit, J, Kjaer, U 2009, 'Split-ticket voting in times of sub-national government reorganization: Evidence from Denmark', Scandinavian Political Studies, vol. 32, no. 4, pp. 422-439.

Erlingsson, GÓ, Ödalen, J 2017, 'A normative theory of local government: Connecting individual autonomy and local self-determination with democracy', Lex Localis - Journal of Local Self-Government, vol. 15, no. 2, pp. 329-342.

Erlingsson, GÓ, Ödalen, J, Wangmar, E 2015, 'Understanding large-scale institutional change: Social conflicts and the politics of Swedish municipal amalgamations, 1952-1974 Scandinavian Journal of History, vol. 40, no. 2, pp. 195214.

Fahey, G, Drew, J, Dollery, B 2016, 'Merger myths: A functional analysis of scale economies in New South Wales local government', Public Finance and Management, vol. 16, no. 4, pp. 362-382.

*Fathimath, A 2017, 'Impact of municipal amalgamation on stakeholder collaboration: The case of Auckland, New Zealand', Kōtuitui: New Zealand Journal of Social Sciences Online, forthcoming.

*Foged, SK 2016, 'The relationship between population size and contracting out public services: Evidence from a quasiexperiment in Danish municipalities', Urban Affairs Review, vol. 52 , no. 3 , pp. 348-390.

Furukawa, A 2014, 'Asymmetric local government consolidations with heterogeneous local public goods', Theoretical Economics Letters, vol. 4, pp. 305-310.

*Hanes, N 2015, 'Amalgamation impacts on local public expenditures in Sweden', Local Government Studies, vol. 41 , no. 1 , pp. 63-77.
*Hanes, N, Wikström, M 2008, 'Does the local government structure affect population and income growth? An empirical analysis of the 1952 municipal reform in Sweden', Regional Studies, vol. 42, no. 4, pp. 593-604.

*Hansen, SW 2014, 'Common pool size and project size: An empirical test on expenditures using Danish municipal mergers', Public Choice, vol. 159, pp. 3-21.

*Hansen, SW, Houlberg, K, Pedersen, LH 2014, 'Do municipal mergers improve fiscal outcomes?', Scandinavian Political Studies, vol. 37, no. 2, pp. 196-214.

*Hirota, H, Yunoue, H 2017, 'Evaluation of the fiscal effect on municipal mergers: Quasi-experimental evidence from Japanese municipal data', Regional Science and Urban Economics, vol. 66, pp. 132-149.

${ }^{*}$ Houlberg, K, Pedersen, LH 2015, 'Political consensus and fiscal outcomes', Local Government Studies, vol. 41, no. 1, pp. 78-99.

Howell-Moroney, M 2008, 'The Tiebout Hypothesis 50 Years Later: Lessons and Lingering Challenges for Metropolitan Governance in the 21st Century', Public Administration Review, vol. 68, no. 1, pp. 97-109.

*Jakobsen, M, Kjaer, U 2016, 'Political representation and geographical bias in amalgamated local governments', Local Government Studies, vol. 42, no. 2, pp. 208-227.

*Jordahl, H, Liang, C-Y 2010, 'Merged municipalities, higher debt: on free-riding and the common pool problem in politics', Public Choice, vol. 143, pp. 157-172.

Kelleher, C, Lowery, D 2004, 'Political Participation and Metropolitan Institutional Contexts', Urban Affairs Review, vol. 39, no. 6, pp. 720-757.

*Kjaer, U, Hjelmar, U, Olsen, AL 2010, 'Municipal amalgamations and the democratic functioning of local councils: The case of the Danish 2007 structural reform', Local Government Studies, vol. 36, no. 4, pp. 569-585.

*Kjaer, U, Klemmensen, R 2015, 'What are the local political costs of centrally determined reforms of local government', Local Government Studies, vol. 41, no. 1, pp. 100-118.

Kortt, MA, Dollery, B, Drew, J 2016, 'Municipal mergers in New Zealand: An empirical analysis of the proposed amalgamation of Hawke's Bay Councils', Local Government Studies, vol. 42, no. 2, pp. 228-247.

*Krøtel, SML, Villadsen, AR, Hansen, MB 2017, 'What to do here? What to do there? The effect of change in organization size on public management', International Public Management Journal, forthcoming.

*Kushner, J, Siegel, D 2003, 'Citizens' attitudes toward municipal amalgamation in three Ontario municipalities', Canadian Journal of Regional Science, vol. 26, no. 1, pp. 49-59.

*Kushner, J, Siegel, D 2005, 'Are services delivered more efficiently after municipal amalgamations?', Canadian Public Administration, vol. 48, no. 2, pp. 251-267.

*Kushner, J, Siegel, D 2005a, 'Citizen satisfaction with municipal amalgamations', Canadian Public Administration, vol. 48, no. 1 , pp. 73-95.

*Lassen, D, Serritzlew, S 2011, 'Jurisdiction size and local democracy: Evidence on internal political efficacy from large-scale municipal reform', American Political Science Review, vol. 105, no. 2, pp. 238-258.

Lidström, A 2013, 'Citizens in the city-regions: Political orientations across municipal borders', Urban Affairs Review, vol. 49, no. 2, pp. 282-306.

Lithopoulos, S 2015, 'A literature review on the amalgamation of police services in Canada', Research Report: 2015-R014, Ottawa, ON: Public Safety Canada.

Lowery, D 2000, 'A Transaction Costs Model of Metropolitan Governance: Allocation Versus Redistribution in Urban America', Journal of Public Administration Research and Theory, vol. 10, no. 1, pp. 49-78. 
*Mabuchi, M 2001, Municipal amalgamation in Japan, Washington, DC: World Bank.

*Miljan, L, Spicer, Z 2015, Municipal amalgamation in Ontario, Ontario Prosperity Initiative, Vancouver: Fraser Institute.

*Miyazaki, T 2017, 'Examining the relationship between municipal consolidation and cost reduction: An instrumental variable approach', Applied Economics, forthcoming.

*Moisio, A, Uusitalo, R 2013, 'The impact of municipal mergers on local public expenditures in Finland', Public Finance and Management, vol. 13, no. 3, pp. 148-166.

Mussari, R, Ruggiero, P 2017, 'Merging for capacity and a capacity for merging: Politicians, citizens and discourses in public administrations', Financial Accountability \& Management, vol. 33, no. 1, pp. 27-47.

*Nelson, MA 1992, 'Municipal amalgamation and the growth of the local public sector in Sweden', Journal of Regional Science, vol. 32, no. 1, pp. 39-53.

Newton, K 1982, 'Is small really so beautiful? Is big really so ugly? Size, effectiveness, and democracy in local government', Political Studies, vol. 30, no. 2, pp. 190-206.

Oakerson, R 1999, Governing Local Public Economies: Creating the Civic Metropolis, Oakland, CA: ICS Press.

Oakerson, RJ 2004, 'The Study of Metropolitan Governance', In R. Feiock (Ed.), Metropolitan Governance: Conflict, Competition, and Cooperation, Washington, DC: Georgetown University Press. pp. 17-45.

Oates, WE 1972, Fiscal Federalism, New York: Harcourt, Brace and Jovanovich.

Oates, WE 1999, 'An Essay on Fiscal Federalism', Journal of Economic Literature, vol.37, pp. 1120-1149.

Oliver, JE 2001, Democracy in Suburbia, Princeton, NJ: Princeton University Press.

Ostrom, V, Tiebout, C, Warren, R 1961, 'The Organization of Government in Metropolitan Areas: A Theoretical Inquiry', American Political Science Review, vol. 55, no. 4, pp. 831-42.

Rusk, D 1999, Inside Game Outside Game: Winning Strategies for Saving Urban America, Washington DC: Brookings Institution Press.

*Poel, DH 2000, 'Amalgamation perspectives: Citizen responses to municipal consolidation', Canadian Journal of Regional Science, vol. 23, no. 1, pp. 31-48.

${ }^{*}$ Reese, L 2004, 'Same governance, different day: Does metropolitan reorganization make a difference?', Review of Policy Research, vol. 21, no. 4, pp. 595-611.

${ }^{*}$ Reingewertz, Y 2012, 'Do municipal amalgamations work? Evidence from municipalities in Israel', Journal of Urban Economics, vol. 72, pp. 240-251.

Rizzi, D, Zanette, M 2017, 'A procedure for the ex-ante assessment of compulsory municipal amalgamation policies', Public Finance and Management, vol. 17, no. 2, pp. 170-201.

${ }^{*}$ Roesel, F 2017, 'Do mergers of large local governments reduce expenditures? Evidence from Germany using the synthetic control method', European Journal of Political Economy, vol. 50 , pp. 22-36.

*Ryan, R, Hastings, C, Grant, B, Lawrie, A, Shé, ÉN, Wortley, L 2015, 'The Australian experience of municipal amalgamation: Asking the citizenry and exploring the implications', Australian Journal of Public Administration, vol. 75, no. 3, pp. 373-390.

*Saarimaa, T, Tukiainen, J 2015, 'Common pool problems in voluntary municipal mergers', European Journal of Political Economy, vol. 38, pp. 140-152.

Sancton, A 1996, 'Reducing costs by consolidating municipalities: New Brunswick, Nova Scotia and Ontario', Canadian Public Administration, vol. 39, no. 3, pp. 267-289.

Sinnewe, E, Kortt, MA, Dollery, B 2015, 'Is biggest best? A comparative analysis of the financial viability of the Brisbane
City Council', Australian Journal of Public Administration, vol. 75 , no. 1, pp. 39-52.

*Slack, E, Bird, R 2013, 'Does municipal amalgamation strengthen the financial viability of local government? A Canadian example', Public Finance and Management, vol. 13, no. 2, pp. 99-123.

Sørensen, RJ 2006, 'Local government consolidations: The impact of political transaction costs', Public Choice, 127, 75-95.

*Spicer, Z 2012, 'Post-amalgamation politics: How does consolidation impact community decision-making?', Canadian Journal of Urban Research, vol. 21, no. 2, pp. 90-111.

*Steiner, R 2003, 'The causes, spread and effects of intermunicipal cooperation and municipal mergers in Switzerland', Public Management Review, vol. 5, no. 4, pp. 551-571.

*Steiner, R, Kaiser, C 2017, 'Effects of amalgamations: Evidence from Swiss municipalities', Public Management Review, vol. 19, no. 2, pp. 232-252.

Strebel, MA 2016, 'Incented voluntary municipal mergers as a two-stage process: Evidence from the Swiss Canton of Fribourg, Urban Affairs Review, forthcoming.

*Suzuki, K, Sakuwa, K 2016, 'Impact of municipal mergers on local population growth: An assessment of the merger of Japanese municipalities', Asia Pacific Journal of Public Administration, vol. 38, no. 4, pp. 223-238.

Swianiewicz, P 2002, Size of local government, local democracy and efficiency in delivery of local services-International context and theoretical framework', In $\mathrm{P}$ Swianiewicz (ed.), Consolidation or fragmentation? The size of local governments in Central and Eastern Europe, chapter 1, pp. $1-29$.

Swianiewicz, P 2010, 'If territorial fragmentation is a problem, is amalgamation a solution? An East European perspective', Local Government Studies, vol. 36, no. 2, pp. 183-203.

Swianiewicz, P 2018, 'If territorial fragmentation is a problem, is amalgamation a solution? - Ten years later', Local Government Studies, vol. 44, no. 1, pp. 1-10.

*Takagishi, Y, Sakata, M, Kitamura, T 2012, 'Influence of the municipal merger on local government employees' stress response in Japan', Industrial Health, vol. 50, pp. 132-141.

Tavares, A 2015, 'Reformas territoriais: Fusões de municípios e cooperação intermunicipal', In de Sousa, L, Tavares, A, da Cruz, NF, Jorge, S (eds.), A reforma do poder local em debate, Lisboa: ICS.

Tavares, AF, Rodrigues, M 2015, 'The economic and political impacts of top-down territorial reforms: The case of Portuguese parishes', Local Government Studies, vol. 41, no. 6, pp. 956-976.

Thuesen, AA 2017, 'Local democracy in large municipalities: Cocreating democracy and rural development through multilevel participation structures and local development plans', Town Planning Review, vol. 88, no. 3, pp. 327-348.

Tiebout, CM 1956, 'A Pure Theory of Local Expenditures', Journal of Political Economy, 64, pp. 416-424.

Verba, S, Nie, NH 1972, Participation in America: Political Democracy and Social Equality, Chicago, IL: The University of Chicago Press.

*Vojnovic, I 2000, 'The transitional impacts of municipal consolidations', Journal of Urban Affairs, vol. 22, no. 4, pp. 385-417.

Weiher, G 1991, The Fractured Metropolis: Political Fragmentation and Metropolitan Segregation, Albany: State University of New York Press.

*Zeedan, R 2017, 'Bigger but not always better: Size and democracy in Israeli amalgamated local governments', Journal of Urban Affairs, vol. 39, no. 5, pp. 711-728. 